The Philosophical Journal of Conflict and Violence

Vol. III, Issue $1 / 2019$

(C) The Authors 2019

Available online at http://trivent-publishing.eu/

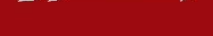

\author{
Imago Dei \\ A Schellingian Reflection on Violence and Evil \\ Saitya Brata Das \\ Jawaharlal Nehru University, New Delhi, sbdas@mail.jnu.ac.in
}

\begin{abstract}
That the senselessness of violence - violence no longer a mere political means to a justified end outside it - is omnipresent in today's world: the realization of this truth appears to have made obsolete today the conventional understanding of violence as mere political means. That the Greeks thought "bia," which means violence, in its close proximity with "bio," which means "life," speaks not surprisingly a truth whose manifestation we perceive today more clearly than ever before, albeit the mode or manner of this manifestation today was perhaps not known to the Greeks. Taking F.W.J. von Schelling's reflection on evil and violence as the point of departure, this paper seeks to understand the relation between life and violence anew and attempts to show that at the heart of the phenomenon of evil lies the enigmatic and fascinating question of the image.
\end{abstract}

Keywords: Hegel; Schelling; Concept; Evil; Imago Dei; Violence.

DOI: 10.22618/TP.PJCV.20193.1.192008

The PJCV Journal is published by Trivent Publishing

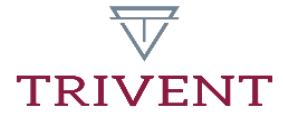

This is an Open Access article distributed in accordance with the Creative Commons Attribution Non Commercial (CC$B Y-N C$-ND 4.0) license, which permits others to copy or share the article, provided original work is properly cited and that this is not done for commercial purposes. Users may not remix, transform, or build upon the material and may not distribute the modified material (bttp:/ / creativecommons.org/licenses/by-nc/4.0/) 


\title{
Imago Dei \\ A Schellingian Reflection on Violence and Evil
}

\author{
Saitya Brata Das \\ Jawaharlal Nehru University, New Delhi, sbdas@mail.jnu.ac.in
}

\begin{abstract}
That the senselessness of violence - violence no longer a mere political means to a justified end outside it - is omnipresent in today's world: the realization of this truth appears to have made obsolete today the conventional understanding of violence as mere political means. That the Greeks thought "bia," which means violence, in its close proximity with "bio," which means "ife," speaks not surprisingly a truth whose manifestation we perceive today more clearly than ever before, albeit the mode or manner of this manifestation today was perhaps not known to the Greeks. Taking F.W.J. von Schelling's reflection on evil and violence as the point of departure, this paper seeks to understand the relation between life and violence anew and attempts to show that at the heart of the phenomenon of evil lies the enigmatic and fascinating question of the image.
\end{abstract}

Keywords: Hegel; Schelling; Concept; Evil; Imago Dei; Violence.

\section{Introduction: The Intrigue}

That the senselessness of violence - violence no longer a mere political means to a justified end outside it - is omnipresent in today's world: the realization of this truth, once it has arrived, appears to have made obsolete today the conventional understanding of violence as mere political means. Violence as a political means, especially in wars that the state wages for the reason of its existence, is thought to be more or less determinable as to its source and topos. The absence of this topos/locality -this also means the absence of its determinable "totality" - defines today the character of the new totalitarianism of violence and its omnipresence that now threatens to invade every cells of our individual and social life. That the Greeks thought "bia," which means violence, in its close proximity with "bio," which means "life", speaks not surprisingly a truth whose manifestation we perceive today more clearly than ever before, albeit the mode or manner of this manifestation today was perhaps not known to the Greeks. Not so far is also the Latin sense of "vis" (which is the word for violence) in its proximity with "vita" (the word for life). What, then, is the intrigue that binds and unbinds "bia" with "bio," "vis" with "vita," "violence" with "life"?

A philosophical reflection on violence cannot escape this intrigue that indeed makes violence violent, an intrigue that challenges reflection itself as to its efficacy and sense, especially in today's world when violence has become an ineluctable part of our daily life, and more especially in certain parts of the globe where savage violence is as banal - in Hegel's memorable phrase -as swallowing a mouthful of water, or cutting the head of a cabbage. ${ }^{1}$ This banality of violence that assaults life, or rather capsizes life, as the pirates capsize the merchants" ships, has not however made our "experience" of violence- if at all can it be called "experience" - any more bearable or tolerable, or any less tyrannical and barbaric. Living in

${ }^{1}$ Georg Wilhelm Friedrich Hegel, Phenomenology of Spirit, trans. A.V. Miller (Oxford: Oxford University Press, 1977), 360. 
the midst of such banal and yet savage violence, where living means none other than simply "going on..." or "surviving...",philosophical reflection on violence lacks the necessary distance for reflection itself to be possible, if not adequate: the unbearable light of its manifestation today has condensed itself into such a dazzling night that our eye cannot contemplate it, let alone cognize it, in the "suffering" and "patience" of the concept, as Hegel once thought it to be possible. ${ }^{2}$ But this failure of thought, its wounds and fractures, which itself cries out in suffering from violence, has the poignancy and pregnancy which otherwise the patient work of the dialectical concept necessarily lacks, and is only symptomatic of the event that today we need a thinking, if it is still to be called " philosophical," which is not dialecticalconceptual.

\section{Violence of the Concept}

For there is indeed something like "violence of the concept" itself which - like the operation of the law - works through the logic of subsumption and integration. The law of the concept or the concept of the law, in its "maximizing thrust of language" subsumes the singularity under the fold of the universal: "the tragic denial" of the singular ${ }^{3}$ that installs or institutes hegemonies. Hegemonies, therefore, are founded upon a violent phantasm, a fiction, a myth, which is the power of nothing, yet which is the very power of power itself, because it grounds itself on nothing; it is the nothingness which, absenting itself and emptying all actuality or "being", institutes the edifice of all hegemonies. The paradoxical power of this nothingness, the power that presupposes 'the tragic denial' of the singular, is the very power of the concept: it is in 'this maximizing thrust of language 'that the integrative violence of the law lies.

Any rigorous reflection on violence, then, should attend to this phantasmatic and mythic character of violence, which rests on nothing, but does not remain there, which is, as mere nothing, for it is this malicious and devouring hunger for being where its violence, and its radical evil lies: that is, its totalitarian claim to be total and absolute everywhere. This claim to universality through 'the tragic denial' of singulars: such dialectical-conceptual language cannot serve for us as a "critique" of violence, if we still want to retain the word "critique" here. The decision of the concept and the decisionist violence of this decision lie- as the very word "de-cision" (Ent-scheidung) itself implies- in its cutting itself away from life, from life as life (the life of singulars, the singular life of the singular being). The surgical strike on the non-identical and incorporation of the non-identical into the integrative fold of the law: this law of the concept is forever incommensurable, as the irreducible and disparate, with life as life, which singularizes each one of us, and each one alone. Despite "the tragic denial," such affirmation of life as life remains as "undertow" of each hegemonic artifice, each time exposing its hegemonic phantasm to be nothing other than a phantasm: when that happens, as Reiner Schürmann insists, hegemonies destitute themselves, and get broken.

Such, then, is the task of the critique of violence: to release the element of singularity from the violent seizing of life by exposing the undertow that destitutes hegemony. That is why the conceptual language of dialectics-which does not know the tragic disparate between the universal and the singular- is replaced by Schelling and Rosenzweig, each in his own fashion, with "narrative-thinking" (Schelling) and "language-thinking"(Sprachdenken: Rosenzweig), that is: thinking nourished by the event of time, non-totalizable, escaping the violent gaze of the law (law that transfixes existents).

\footnotetext{
2 Ibid., 10.

${ }^{3}$ Reiner Schürmann. Broken Hegemonies, trans. Reginald Lilly (Indiana University Press, 2003).
} 
From Schelling to Rosenzweig via Kierkegaard, it is always the question of escaping from - while putting into question - the metaphysical violence of the concept, for at stake here is none other than the immense question of the politico-theological foundation of authority: the gathering act by the concept the multiple singularities of existents into self-presence (from which a certain arché-violence is ineluctable). Arché: principle, but also institution in the sense of the verbal beginning and installation - such grounding and founding of political authority would not be possible without the gathering, by violent acts of integration and subsumption, of being into singular plurals: in other words, this arché-violence erupts from the thetic-positing character of the concept, where the concept serves itself as the juridical authority. The selflegitimizing character of the concept, with all its juridico-political-theological resonance, has the character of auto-poesis, which we have learned to call "mythic", especially after Walter Benjamin's essay, ${ }^{4}$ for what Benjamin means by "mythic violence" is precisely the auto-poetic thetic violence that accompanies the founding or grounding act of political authority out of nothing: a fantastic and phantasmatic act that posits itself as itself, like the self-positing character of the concept, pre-supposing nothing outside itself, a nothingness, which for that matter is all the more potent and is the source of power as such. An anarchic critique of violence would, then, demand the kenotic emptying of potentia from the law and the interruption of the violence that lies in the thetic-positing character of the concept (where the concept serves itself as the juridical-political authority in philosophical discourse). The critique should be able to disclose that the figure of worldly sovereignty, in order to elicit from us normative obligations, constantly needs to legitimatize itself; it, thus, appeals to a phantasm that gives itself a foundation, as if out of nothing (an auto-poetic thetic act from which an arché-violence is inseparable).

To rescue the element of singularity from the integrative violence of the law is to think of an actuality that will not be subsumable to the mythic-thetic totality of potentiality; that is, it is to think of the outside, which thereby does not serve as the transcendental-legislative auctoritas of the law; rather, it is to think the exception that kenotically empties out from the concept all its attributes of sovereignty, all the predicates of potentiality. It is this anarchic emptying out of sovereignty that Schelling attempts to think in the name of "actuality without potentiality."

\section{The Abyss of Evil}

Schelling's more systematic and rigorous reflection on violence is inseparable from his thinking of evil that is to be found in the so-called middle Schelling, namely, in his great 1809 essay on the Essence of Human Freedom and his Private Lectures at Stuttgart a year later, and also in his incomplete magnum opus Die Weltalter: images of sickness and disease, of evil and its allconsuming hunger for being all abound in these texts from his middle period. That Hegel considered Schelling's near obsession with the question of evil to be his singular contribution to the history of western metaphysics: this is at once correct to a certain extent, and yet a biased appreciation of Schellingian thought, for what Schelling wanted to think is not that of evil as one question among others, but the very ontological question of philosophy itself in an originary manner; for the question of violence, in its intimacy with the phenomenon of evil, belongs to the great and originary problematic of philosophy, namely, the essence of human freedom.

\footnotetext{
${ }^{4}$ Walter Benjamin, “The Critique of Violence," in Reflections, ed. Peter Demetz (New York: Schocken Press, 1986), 277-300.
} 
In his 1809 essay on human freedom where the most rigorous reflection on evil is to be found, Schelling draws the astonishing analogy between sickness and evil: what sickness is in the realm of nature, evil is in the realm of freedom; and if violence is essentially connected with the phenomenon of evil, then violence, thought in its utmost rigor, cannot strictly be thought to belong to the realm of nature. This is not because the human being, as subject, possesses freedom as its property, or appropriates it as possession; rather - and this is important - the human being is first of all opened up in the open space of freedom in the manner of - how to say this? - always already "loaned" to him/her, as it were: the being of this very humanity itself is a "loaned" being, given as gift in an originary manner, arriving from a source which can never be appropriated and possessed as property. This non-autochthony and non-aboriginal mode of being as gift, given in an abounding abyss of divine love, is the very condition of possibility of human freedom, which, precisely thereby, remains "inscrutable" to human reason.

This, then, is the original violent act of the human being who is opened in the Open of freedom: to institute, to install, or to posit itself as aboriginal and autochthonous Subject of freedom, and thereby possess its own being as sovereign figure. In itself, it is "non-being," given to it as gift out of the abyss of the divine love (for this gift itself could not come from the divine power): the divine has to kenotically empty itself, and renounce its power so that another being, finite and creaturely, be made in the image of the divine, may come into being at all. This originary "constriction," "concentration" or " restriction" on God's part - as Schelling speaks of it in his 1810 Stuttgart lectures, almost in a Kabbalistic manner (as Gershom Scholem first remarked) - is a renunciation of violence on God's part (for the naked manifestation of the power of God is only annihilation of the mortals). Thus, the divine Love, preceding evil and thereby even goodness, is God's original act of renouncing his own violence: where Love is, there is no judgement, and there is no force, even if it is the force of God. Love and judgement are incommensurable.

If we try to draw out the consequences of Schellingian thought here, a peculiar transformation of the traditional understanding of Imago Dei occurs: the human being is created in the image of God, which means: the image of God's renunciation of his violence, and not as the image of divine omnipotence. Here, the image is the image of Love as the divine gift to mortals, where God withdraws his force of judgement. If the human being is thereby called "sovereign" or "lord" in the earthly order, this sovereignty is not the sovereignty of power but the sovereignty of im-potentia: that is, the mortal's infinite and unique responsibility, as the elected or chosen race, towards other creaturely beings on earth, and its obedient service as the nexus of beings. The image - Imago Dei - speaks here of the mortal's unique, absolutely irreplaceable and infinite responsibility, a responsibility not only to the divine, whose image that $\mathrm{s} /$ he is, but also to the other creaturely beings on earth. As creaturely like any other creatures on earth, and yet, bearing the divine image, the mortal is the paradoxical (creaturely, and yet bearing the image of the uncreated) being, who is the unique centre of beings; s/he is the heart of beings, the hinge on which the nexus of beings rests. The entire creaturely order of beings palpitates - as the heart does - in the mortal being: "Only man is in God," writes Schelling, and "through this very being-in-God is capable of freedom. He alone is a central being and therefore should also remain in the centre. In him all things are created, just as it is also through man that God accepts nature and ties it to him." 5

Thus, the decision of the human being, arising out of the abyss of human freedom (which itself is the image of divine freedom), may couple or un-couple, distort or forge, join or disjoin in a creative way, inversely or harmoniously bring together, this nexus of beings. Because

\footnotetext{
${ }^{5}$ Friedrich Wilhelm Joseph von Schelling, Philosophical Inquiries into the Nature of Human Freedom, trans. James Gutmann (La Salle, Illinois: Open Court, 1936), 92.
} 
human being is truly free, as God is free - and hence mortality is the image of God - the mortal is free even to be un-free: this un-freedom, this perversion of freedom, belongs to the essence to freedom itself, and not vice-versa. The possibility of evil, but not its actuality, ${ }^{6}$ belongs to the essence of freedom itself: without this freedom, or rather without this self-abnegation of freedom, there can be only sickness but not evil. The perversion, inversion, or distortion that entirely transforms the nexus of beings is the very inversion of the image. Instead of the Imago Dei in which the mortal is created, we have now - because of this distortion of the image - another image, the violent image, the image that is the source of violence against which we read, in Exodus: 'Thou shalt not make unto thee a graven image, nor any manner of likeness of anything that is in Heaven above, or that is in the earth beneath, or that is in the water under the earth' (Exodus 20:4).

In his celebrated essay "The Mystical Shape of Godhead”, Gershom Scholem shows that two different words are used in the Old Testament for these two images: the word Tselem is used for image in Genesis (1:26-27), but the word Temunah is used in Exodus (20:4). ${ }^{7}$ The mortal is created in Tselem- the image - of God but s/he shalt not make Temunab-image - of God: between these two images lies the immense abyss of violence that the mortal can unleash out of the gift of freedom, that is, the freedom to distort, invert and pervert Tselem into Temunah. This violence- violence that erupts out of the transmutation of Tselem into Temunab-is to be distinguished from the divine violence that God himself, out of his love for the creaturely, restrains, weakens, constricts and renounces. This latter, the divine violence, more violent than any violence, comes out of the abyss of divine presence: it is the violence of God's dazzling presence that annihilates the law of creaturely being, that darkens the light in which presence becomes for mortals a possible manifestation or an appearance, while the divine presence-in-himself remains invisible, incomprehensible and unknowable.

The whole Schellingian reflection on violence and evil is concentrated here. The will of the particular, which should serve merely as the principle of ground, seeks to universalize itself, and wants to appropriate the whole of beings; in itself only the principle of finitude, itself lacking being, it is in malicious hunger for being, like an all-devouring, consuming fire that burns without expiation and without satiation. Like the sickness of an organ which spreads its sickness to the whole of the body in a contagious manner, evil spreads itself in order to attain being while forever lacking it, and lacking it, becoming even more devouring. Evil is, then, precisely this: the malicious hunger of nothingness for being; the principle of ground no longer seeking to remain ground, and thus, seeking to attain existence; the particular will's self-abnegation, and its forever impotent desire to universalize itself as everywhere total and absolute will. The paradoxical character of evil and its totalitarian violence - a violence that lacks all determinable totality and locality - lies in this overwhelming potentiality which is, after all, impotent, or, its impotentiality, which is such an overwhelming potentia. Evil, then, does not lie either in the particular will or in the will of the universal; it is rather the will of the particular to attain universality by its "maximizing thrust."

As consequence of this insatiable hunger of nothingness for being, the whole nexus of beings gets distorted, inverted, contorted and perverted. The mortal, who as the Imago Deias the image of God - serves as the verbal link between creaturely beings and the divine, distorts and perverts its very being-as-image, and transforms this original image into Temunab(the image which is the source of all the violence that emanates from idolatry). The mortal now

\footnotetext{
${ }^{6}$ Schelling makes the distinction between possibility and actuality.

${ }^{7}$ See Gershom Scholem, "Shi'urKomah: The Mystical Shape of the Godhead," in On the Mystical Shape of the Godhead: Basic Concepts in the Kabbalah, trans. Joachim Neugroschel (New York: Schocken Books, 1991), 15-55.
} 
no longer seeks to remain as the image -Tselem - of God: s/he no longer wants to remain "the central being" who, in likeness to God, must renounce all violence so that the order of creation remains tied to God; rather, now s/he wants to be the very image - Temunah - of God, to be the likeness of God in His sovereign power and divine presence. In this transformation of Tselem to Temunah - of image to image - there occurs the transformation of sovereign Love into the sovereignty of power. The image now becomes the very source and origin of (earthly) power; in other words, the whole of idolatry lies in its power-making violence, and it appeals to the theological foundation (divine power) in order to justify it. The immense question of the politico-theological foundation of authority, then, hinges on this phenomenon of the image, or rather, on this transmutation of image to image. The image of Imago Dei is perverted into a phantasm, into a fiction constitutive of hegemonic powers in the earthly orders of politics.

This would not have been possible if the mortal had not been granted freedom: the possibility of radical evil, and the possibility of all violence emanating from evil, lies in this abyssal ground of freedom; yet, without this freedom, the human being cannot be the Imago Dei, and would not be the redeeming, central being, the verbal link between nature and God. This is the double bind of freedom: evil is the inextricable possibility of the human being in its very being as Imago Dei; but, this does not mean that the mortal is essentially and necessarily evil, for possibility and actuality can never be identical in the case of the human being (unlike God).

The gift of the image -Imago Dei - is the very gift of being mortal, and yet, this "being," precisely because it is "loaned", is also, in another sense, a non-being; in other words, it is the principle of his/her finitude: the mortal being is that which - being image - is non-being. Image "is" non-being; it is nothing, in the sense that it is the renunciation of violence that emanates from presence: hence the redemptive, paradisiacal melancholy of Adam that both Schelling and Benjamin speak of, that irreducible veil of melancholy that comes from the finitude of the mortal who cannot absolutely actualize all of his possibility. On the other hand, that image, the image in which the mortal, abusing his/her gift of freedom, seeks to attain the sovereignty of power in the likeness of God, is the nothingness that bears the malicious, violent hunger for being, and unleashes violence without expiation and without atonement. This latter image is the very image of judgement: because of the Fall of the central being, the whole nexus of beings too gets broken; now the whole of nature, as St Paul writes in his letter to the Romans, groans and suffers for redemption: "For we know that the whole creation groaneth and travaileth in pain together until now. And not only they, but ourselves also, which have the first fruits of the Spirit, even we ourselves groan within ourselves, waiting for the adoption, to wit, the redemption of our body. For we are saved by hope for that we see not, then do we with patience wait for it' (Romans, 8: 22-24). This is not the paradisiacal melancholy of blissful nature named by Adam, but the melancholy that suffers the violence of judgement. The violence of judgement results from the mortal's malicious hunger to institute itself, instead of itself as Imago Dei, as the sovereign, autochthones, and aboriginal figure who seeks to appropriate, not only the whole creaturely order but being itself, and thereby selfabnegates the very principle of finitude that is the source of its "being". Lacking being, evil does not have a face of its own; however, in its insatiable hunger for being, evil maliciously seeks to appropriate all faces, thereby de-facing the face of the existent: this is where the metaphysical violence lies that evil is capable of unleashing upon existence.

\section{Inspiration from Plato}

The question of the image is already fundamental to Schelling's 1804 essay Philosophy and Religion, written five years before the essay on human freedom. Followed by his incomparably 
beautiful dialogue Bruno, this essay from 1804 marries the Platonic conception of the originary image (and counter-image) with the Christian conception of the fall, in a manner that recalls the early Church Fathers like Gregory of Nyssa. The possible influences of the early Church Fathers - especially someone like Gregory of Nyssa - on Schelling, especially on the early Schelling (of Bruno and Philosophy and Religion), still need to be investigated. Reacting against the vulgar neo-Platonic conception of emanation that explains the origin of phenomenal world from the Godhead 'in gradual increments and detachment from the originary source', ${ }^{8}$ Schelling posits the Christian idea of the falling away - or remove (Entfernung) - in Platonic manner so as to "abandon the idea of continuity between the phenomenal universe and divine perfection, for only then will the later manifest itself in its true nonbeing." 9

At stake here is again the question of the theologico-political: this non-continuity or this idea of radical interruption (between divine perfection and phenomenal universe) makes impossible any attempts on the part of earthly sovereign power to trace it back to divine power. Schelling puts his words here in italics: "no finite thing can directly originate from the Absolute or be traced back to it." 10 The divine, then, cannot be understood to be the sanctioning and legitimating authority for any worldly powers: "there is no continuous transition from the Absolute to the actual; the origin of the phenomenal world is conceivable only as a complete falling-away from absoluteness by means of a leap." 11 Here is Schelling's radical Christian interpretation of Plato:

According to Plato, the soul can descend from its original state of beatitude and be borne into the temporal universe and thereby torn away from the truth only by means of a falling-away from the originary image (Urbild). This was the tenet of the Greek mystery cult's secret teachings, to which Plato alluded quite explicitly: that the origin of the phenomenal world should not be imagined, as popular religion does, as a creation, as a positive emersion from the Absolute, but as a falling-away from it. ${ }^{12}$

It is clear here that "the falling away" is the falling-away from the image, from "the originary image" (Urbild). The task of philosophy and religion, each in its own manner, is the same: that of restoring that imago by kenotic emptying - "by mortifying the sensate life"-of the worldly powers. Only then can the soul "regain absoluteness and again partake of the intuition of the originary image" (ibid). The question of the phenomenal world is a produced reality of the pseudo-image (Scheinbild) "that is not in itself real but real in relation to the soul and even then only insofar as it has fallen away from the originary image." 13

Where, then, lies the origin of the evil? It does not lie in the originary image itself - in the Imago Dei- but in the soul's subordination or subsumption of "its infinite part to finitude by apprehending itself in selfhood, thereby falling away from the originary image." 14 The originary violence of the mortal lies precisely in this- in the absolute self-assertion of the selfhood (which actually is the principle of finitude) as the sovereign, autochthonous and aboriginal arché. Here the falling away is the falling away from (original) image to (pseudo-)image: the paradisiacal image falls away into the abyss of the pseudo-image (positing itself as sovereign).

${ }^{8}$ Friedrich Wilhelm Joseph von Schelling, Philosophy and Religion,trans. Klaus Ottmann (Putnam:Spring Publications, 2010), 24.

${ }^{9}$ Ibid.

10Ibid., 29.

11Ibid., 26.

12Ibid., 27.

13Ibid., 29.

14Ibid., 40. 
However, "the path toward heaven" - as in Dante's poem - passes through the abyss. ${ }^{15}$ The true, originary image can only be in God - not to be found in the profane, worldly order where morality and beatitude are but two different sides of the same oneness: "God is absolute beatitude and absolute morality in a completely equivalent manner - both are equally infinite attributes of God." 16 If the task of philosophy and religion lies in participating in beatific life - life that is released from the violent grasp of the law - then, it can only be attained by emptying of worldly attributes, and by restoring ourselves as true Image Dei.

\section{The Broken Nexus}

Schelling deepens this insight in the series of private lectures that he gave at Stuttgart a year later. The event of the Fall marks - so Schelling continues in his 1810 Private lectures - the breakage or fissure into the nexus of beings (God-man-nature): the jointure of beings is disjoined. This "disjointure" is the origin of the historical order, the unredeemed state of destitution and evil that has its analogy, in the realm of nature, in sickness. As the created order that can't ground itself on any immanent foundation, the apostate state of history is the realm of mere "passing away" and transience: it is what must, anyway, by the very logic of its origin, pass away, and is passing away. No "figure" in the apostate order of world-historical existence can claim sovereignty without ultimately having to pass away. It is here we see the Schellingian theologico-political deduction of the state and the church.

The state is the mortal being's impoverished attempt to supplement an absolute impoverishment, namely, the link or the jointure that is broken among beings as consequence of the Fall. As such, the state, like anything in the profane order, is transient: it is this supplement that forcefully tries to affect the lost unity by always making "legitimate" use of power, which is the source of its violence. Far from seeing the state as the figure of the Absolute, the state is thought here as precarious and fragile (the order of non-being), and precisely thereby being dangerous and tyrannical: the violence of the state lies not in the power of its being, but in its malicious, devouring hunger for being. This totalizing tendency is the intrinsic logic of its very "(non-)being"; the state is potentially - because it is ruled by power alone - unjust and tyrannical: that means, any worldly regime, ruled by any earthly sovereign power, always has the potentiality to go wrong.

What the state is in the external realm, the church is in the internal realm: an attempt to supplement the lost nexus among beings. The insufficient and precarious character of the state, which is instituted as supplement of the lost nexus of beings, demands the second revelation to restore the lost unity: Christ here being the mediator between God and man, himself God-man, dying the most ignoble death on the cross, and bearing the intolerable suffering and evil only to redeem the unredeemed condition of the fallen state. So the church is the immediate consequence of the second revelation. But insofar as the church, in the process of its historical evolution as an institution, takes part in negotiations with worldly potestas and allies itself with the state, it forgets its initial eschatological impulse - that burning desire for the end of the unjust world, and for the freedom from earthly ties (both ties with the sovereign power of the Roman empire, and the family ties of oikonomia) - and becomes just like any other worldly institution: the church here becomes the very theological foundation of worldly sovereignties. The Schellingian deconstruction of the political-theological legitimation of worldly sovereignty is nowhere as explicit as here. Far from deifying the profane order of world-historical becoming, and far from seeing the modern state of Prussia as the embodiment of divine reason, Schelling here argues for the separation of the theological from the

\footnotetext{
15Ibid., 31.
}

16Ibid., 43. 
political realm. This separation alone can redress "political tyranny" and the horror of universal domination:

In surveying more recent history, which with good reason, is said to begin with the arrival of Christianity in Europe, we note that humanity had to pass through two stages in its attempt to discover or produce a unity; first that of producing an internal unity through the Church, which had to fail because the Church simultaneously sought to become the external unity and eventually attempted to produce external unity by means of the state. Only with the demise of hierarchical [systems] has the state attained this importance, and it is manifest that the pressure of political tyranny has increased ever since in exact proportion to the belief that an inner unity seemed dispensable; indeed it is bound to increase to a maximum intensity until, perhaps, upon the collapse of these one-dimensional attempts humanity will discover the right way. ${ }^{17}$

And therefore,

God, however, as identity of the highest order, remains above all reality and eternally has merely an indirect relationship. If then in the higher moral order the State represents a second nature, then the divine can never have anything other than an indirect relationship to it; never can it bear any real relationship to it, and religion, if it seeks to preserve itself in unscathed pure ideality, can therefore never exist - even in the most perfect State - other than esoterically in the form of mystery cults. ${ }^{18}$

The immense questions of evil and violence can therefore not be understood as mere contingent occurrences of our profane history which otherwise is continuously marching ahead to its pre-determined goal, nor are they mere aberrations in the earthly order of creation; evil is not a mere attenuated variation of the good, the good that the "cunning of reason" realises automatically in the immanent movement of world-history. Schelling considers the phenomenon of violence metaphysically: the result of the broken nexus of beings; the mortal's violent assertion of sovereignty on all other beings on the creaturely order by the use of force; and the mortal's replacement of image (Imago Dei) with another image, this other image that violently distorts and perverts the very being of the mortal. The very original being of the mortal - as Imago Dei - lies in Love, in being responsible to the other creaturely beings on earth. When this Love is replaced with the force of the law, incalculable violence erupts like volcano. Schelling's deduction of the state, and of the church, which is allied with the state, is derived from this metaphysical reflection on the nexus of beings. Schelling thus effectively puts into question the whole legitimacy of the "human" that the philosophical discourse of modernity, in its insistence of autonomy, grounds on its immanent foundation. This metaphysical displacement of anything that is not "human" (whether God or nature) in the name of heteronomy, and instituting the human, not as mortal but as the sovereign figure on earth: it is against this metaphysical violence of modernity Schelling seeks to invoke the old idea of Imago Dei in a Platonic-Christian manner, which demands that the human learn to renounce its sovereignty, and to act, out of his gift of freedom, as an infinitely responsible being, to be what $\mathrm{s} /$ he always already is - the central being, the nexus of all beings, the hinge on which not only his, but the redemption of the whole nature depends. Without the divine whose image

\footnotetext{
${ }^{17}$ Friedrich Wilhelm Joseph von Schelling, Idealism and the Endgame of Theory,trans. Thomas Pfau (Albany: State University of New York Press, 1994), 229.

${ }^{18}$ Friedrich Wilhelm Joseph von Schelling, Philosopby and Religion, 51.
} 
is the human, and without nature to which the human is responsible, the human is not "human," this ecstatic mortal being. Trying to appropriate the abyss of freedom, which is only granted to it as gift, the human then turns demonic, bringing catastrophe to nature and ecological crisis, and thereby indirectly evoking upon itself the violence of divine, eschatological judgement.

\section{Actuality without Potentiality}

Even at the very moment of the institution of German Idealism, a movement towards which the early Schelling himself has contributed, Schelling turns against the fundamental impulses of the Idealist discourse. The early Schelling's critique of the thetic violence of Fichte's primordial act - the act whereby the self founds and grounds and posits itself as itself - is later turned, in a much more vehement form, against the thetic violence of the Hegelian concept of the concept. In this whole span of Schelling's career, right from the instituting moment of the Idealist discourse to the moment of its dissolution in Schelling's own philosophy of revelation, Schelling attempted to release life and to redeem nature from the metaphysical violence of the concept. While Hegel insists on the absolute nature of the absolute concept as the telos of philosophy, Schelling insists on Love - Love even before good and evil, Love unimpaired by the violence of cognition and of conceptual grasp - to be alone redemptive and desirable. But to desire this, reason itself needs to go ecstatic; reason itself must be understood in a way whose very essence is ecstatic, and not the conceptual grasping of phenomena and subsuming them under the "maximizing thrust of language." Hence the famous Schellingian phrase, "ecstasy of reason": reason exposed, open to the outside, to the un-pre-thinkable event without a "why" - to use the phrase from Meister Eckhart - reason exposed open to the outside of all hegemonic order. Towards the outside: this is the true desire of metaphysics- in the sense of "meta" - that Schelling would call "actuality without potentiality," a desire without arché, the desire that does not serve as the legislative principle of the world, the desire that would not form itself into the politico-theological foundation as hegemonic phantasm.

What the later Schelling calls "actuality without potentiality" is actually the idea of exception: transcendence breaking through into the mythic circle of potentiality, interrupting the mythic foundation of all potentiality. The concept, in its maximizing thrust, can grasp, subsume and integrate - and this is the integrative violence of its law - only what is "not-not", only the infinite potentiality of being or the capacity of being (the-what of being), but never the absolute singularity of existence: the singularity of existence- the-that of existence - forever exceeds and escapes the violent grasp of the concept. What the later Schelling calls Positive Philosophy concerns itself, unlike the Negative Philosophy of Hegel, with this singularization that escapes from the maximizing thrust of the concept.

According to Schelling, this absolute event of existence, whose un-pre-thinkable singularity and its ecstatic actuality are beyond the mythic circle of potentiality - and hence, the very event of freedom - remained unthought and unthinkable in the history of western philosophy from Plato to Hegel. The Idealist metaphysics of Hegel, which introduces movement into the concept of being itself, far from being able to address the singularity of existence, subsumes it anew under the universal by a hegemonic phantasm: life is once more captured and transfixed, violently, in the gaze of the law. But if one looks into the mode of operation of the law, one sees that the essence of the law is precisely a nothing, a nothing that is at once violent and powerful, and yet impotent, a mere phantasm or image that has drained existence of all its actuality. That is why Schelling could say that evil, despite its terror, is so fascinating: it draws its force, its violent force, from a nothing which is only the infinite capacity to be. It is neither being nor pure nothing - pure absence of being - that is evil and violent; it is rather that infinite capacity to be and yet, not being in itself - the image -which wants to be only 
being, and nothing else, being absolute and total: this is the totalitarian violence, violence of all and any totalitarian order on the worldly condition. The law-positing violence of the state, which needs constantly to legitimize its violence (its "why") is also drawn from the fantastic and phantasmatic power, or the powerlessness of the image.

Only releasing the singularity - the actuality without potentiality - from the principle of ground, that is, from a certain conception of reason with its maximizing grasp, releasing it via the kenotic abandonment of all worldly potentiality, only this can restore for us the Imago Dei, the other image. For the late Schelling - in fact, even for the early Schelling - this is what religion is truly concerned with: kenotic abandonment of all worldly attributes of the law and entering into the abyss of divine Love. To attain this Life, life as life, not the mere life under the regime of the law - this life that we can truly call "beatitude" or blessedness - we must yet go through the night of abandonment, or the passage of death. Schelling thought this life, this beatific life, life redeemed from the violence of the law, eschatologically: as resurrected life!

He who wishes to place himself in the beginning of a truly free philosophy must abandon even God. Here we say: who wishes to maintain it, he will lose it; and who gives up, he will find it. Only he has come to the ground of himself and has known the whole depth of life who has once abandoned everything, and has himself been abandoned by everything. He for whom everything disappeared and who saw himself alone with the infinite: a great step which Plato compared to death. ${ }^{19}$

In his 1804 essay on Philosophy and Religion Schelling considers philosophy and religion as the two highest activities of the human spirit. In two different ways, philosophy and religion participate in the beatific life through infinite renunciation of violence, and through infinite mortification of worldly powers. Philosophy is not understood here as the cognitive appropriation of the world by the violence of the concept; rather, philosophy here is the infinite task of restoring the Imago Dei through contemplation that renounces the violence of cognition.

\section{References}

Benjamin, Walter. “The Critique of Violence.” In Reflections, edited by Peter Demetz, 277300. New York: Schocken Press, 1986.

Hegel, Georg Wilhelm Friedrich. Phenomenology of Spirit. Translated by A.V. Miller. Oxford: Oxford University Press, 1977.

Heidegger, Martin. Schelling's Treatise on the Essence of Human Freedom. Translated by Joan Stambaugh. Athens: Ohio University Press, 1985.

Schelling, Friedrich Wilhelm Joseph von. Philosophy and Religion. Translated by Klaus

Ottmann. Putnam: Spring Publications, 2010.

Idealism and the Endgame of Theory. Translated by Thomas Pfau. Albany: State University of New York Press, 1994.

Philosophical Inquiries into the Nature of Human Freedom. Translated by James Gutmann. La Salle, Illinois: Open Court, 1936.

Scholem, Gershom. "Shi'urKomah: The Mystical Shape of the Godhead." In On the Mystical Shape of the Godhead: Basic Concepts in the Kabbalah. Translated by Joachim Neugroschel, 15-55. New York: Schocken Books, 1991.

Schürmann, Reiner. Broken Hegemonies. Translated by Reginald Lilly. Indiana University Press, 2003.

${ }^{19}$ Quoted by Martin Heidegger, Schelling's Treatise on the Essence of Human Freedom, trans. Joan Stambaugh (Athens: Ohio University Press, 1985), 6-7. 